\title{
SEKOLAH ALAM LAMPUNG: WADAH PENGEMBANGAN PEMBELAJARAN PENDIDIKAN AGAMA ISLAM (PAI)
}

\section{Lampung Natural School : Learning Development Institusion of Islamism Education}

\author{
Nur Alia \\ Balai Penelitian dan Pengembagan Agama Jakarta \\ Jl. Rawa Kuning Pulo Gebang, Cakung, Jakarta Timur \\ Email: alia.litbang@gmail.com
}

Naskah diterima tanggal 14 Mei 2014. Naskah direvisi tanggal 30 Mei 2014. Naskah disetujui tanggal 6 Juni 2014

\begin{abstract}
Abstrak
Tulisan ini menyajikan hasil penelitian mengenai pengembangan pembelajaran Pendidikan Agama Islam (PAI) di Sekolah Alam Lampung, termasuk di dalamnya metode pembelajaran serta faktor pendukung dan penghambat pelaksanaan PAI. Penelitian dengan menggunakan pendekatan kualitatif ini dilakukan di Sekolah Alam Lampung pada tahun 2011. Hasil penelitian menunjukkan bahwa pembelajaran PAI di Sekolah Alam Lampung menggunakan metode keteladanan, integrasi PAI ke dalam semua mata pelajaran dengan menggunakan model spiderweb, integrasi PAI dalam intra/ekstra-kurikuler, melibatkan seluruh komponen sekolah dan orang tua, mengutamakan praktek dan pengalaman, dan memanfaatkan alam sebagai media pembelajaran. Faktor pendukung berupa kebebasan guru untuk mengeksplorasi metode dan strategi pembelajaran, lingkungan yang kondusif, dan pandangan positif orang tua terhadap tenaga pendidik. Sementara faktor penghambat berkaitan dengan keterbatasan sumber daya tenaga pendidik, perbedaan kemampuan pemahaman agama peserta didik, serta masyarakat yang belum dapat sepenuhnya menerima keberadaan sekolah alam.
\end{abstract}

Kata kunci: pendidikan agama Islam, sekolah alam, spiderweb

\begin{abstract}
This article presents the results of research on the development of learning Islamism Education (PAI) in Lampung Natural School, including teaching methods and the factors supporting and inhibiting Islamism Education implementation. Research using a qualitative approach was conducted in Lampung Natural School in 2011. The results showed that learning Islamism Education in Lampung Natural School used the example method, Islamism Education has been integrated into all subject of the lesson by using a spiderweb model, Islamism integration in intra or extra - curricular, involving all of the school components and parents, giving priority to practice and experience, and utilizing nature as a medium of learning. Supporting factors are teachers are able to explore methods and learning strategy. comfortable environment, and a positive parents opinion towards educators. Whereas inhibiting factors are related to resource restrictiveness of educators, religious understanding differences in the ability of students, and society who have not been able to fully accept the existence of the natural school.
\end{abstract}

Keywords: learning islamism education, the natural school, spiderweb

\section{PENDAHULUAN}

$\mathrm{B}$ erbicara mengenai pendidikan agama khususnya Islam, seakan tak pernah habis oleh kritik. Terlebih jika dikaitkan dengan dekadensi moral yang melanda bangsa ini. Berbagai kasus yang terjadi pada remaja usia sekolah selalu menjadi fokus perhatian masyarakat. Sebut saja kasus narkoba, pergaulan bebas, kriminalitas, ataupun kejahatan di dunia maya. Padahal pada banyak kasus, pelakunya adalah orang dewasa yang notabene seharusnya sudah lebih matang dalam bertingkah laku. Pendidikan agama kemudian disebut menjadi satu-satunya yang harus bertanggung jawab terhadap semua hal tersebut. 
Kegagalan pendidikan agama, seperti dinilai oleh Mochtar Buchori (1992, dalam Muhaimin, 2008:88) disebabkan oleh praktik pendidikan yang hanya memperhatikan aspek kognitif dan mengabaikan aspek afektif dan konatif. Akibatnya terjadi kesenjangan antara pengetahuan dan pengamalan. Dengan kata lain, pendidikan agama berubah menjadi pengajaran agama sehingga tidak mampu membentuk pribadi-pribadi islami.

Kritik lain dinyatakan oleh Muhaimin (2006: 123), kenyataan menunjukkan bahwa pendidikan agama yang selama ini dilaksanakan di sekolah dinilai gagal membentengi moral dan akhlak generasi muda, serta kurang berhasil dalam menggarap sikap dan perilaku keberagamaan peserta didik serta membangun moral etika bangsa.

Menyikapi hal tersebut di atas, seakan tidak mau dipersalahkan, di satu sisi banyak pihak yang terlibat langsung dengan pendidikan agama (khususnya guru agama) mengeluhkan tentang kurangnya jam pelajaran untuk mata pelajaran agama di sekolah. Jam pelajaran yang hanya disediakan 2 jam setiap minggunya disinyalir tidak memadai untuk memberikan pembelajaran agama secara optimal. Sehingga guru agama selama ini terkesan hanya mementingkan tercapainya materi semata tanpa dapat menginternaslisasikan nilainilai agama ke dalam diri peserta didik.

Di sisi lain, beberapa pihak telah berupaya secara nyata untuk mengatasi kritik atas kelemahan pendidikan agama dengan berbagai cara. Maraknya pesantren-pesantren kilat yang diselenggarakan oleh banyak sekolah untuk mengisi liburan misalnya, menjadi salah satu upaya sekolah untuk meningkatkan pemahaman agama siswa dan membentuk sikap yang islami (http://pasitb.tripod. $\mathrm{com} / \mathrm{sanlat} 1 . \mathrm{htm})$. Atau juga dengan digalakkannya lembaga atau komunitas rohani Islam (rohis) dalam bentuk ekstrakurikuler di sekolah-sekolah umum.

Beberapa lembaga pendidikan umum sebenarnya juga telah mengembangkan berbagai upaya kreatif untuk mengoptimalkan pembelajaran pendidikan agama bagi peserta didik. Diantaranya dilakukan oleh SMA Islam Al-Izhar Pondok Labu. Hasil penelitian Aripin (2009) menemukan bahwa pembelajaran Pendidikan Agama Islam (selanjutnya disebut PAI) di SMA Islam Al-Izhar Pondok Labu dilaksanakan dengan pendekatan integratif melalui islamisasi pendidikan dalam wujud: 1) integrasi PAI dalam lingkungan sekolah; 2) integrasi PAI ke dalam semua mata pelajaran umum; 3) interasi PAI dalam intra/ekstra-kurikuler; dan 4) integrasi PAI dalam fasilitas/infrastruktur yang mendukung.
Selain itu, penelitian yang dilakukan oleh Herawati (2009) mengenai pengembangan kurikulum PAI di sekolah alam School of Universe menghasilkan kesimpulan bahwa pengembangan kurikulum PAI dilakukan dengan 3 cara: materi pembelajaran yang dikaitkan dengan kehidupan sehari-hari siswa (kontekstual), metode pembelajaran yang mengutamakan praktek dan pengalaman, dan evaluasi pembelajaran yang berbasis proses.

Penelitian lainnya dilakukan oleh wahyudi (2009) di Sekolah Alam Lampung (selanjutnya disebut SAL), yang menghasilkan temuan bahwa pembelajaran pendidikan agama Islam melalui penerapan pembelajaran terpadu model webbed (jaring laba-laba) terbukti efektif dalam meningkatkan akhlak siswa. Penelitian ini hanya melihat satu aspek saja yakni pembelajaran terpadu model webbed, sementara aspek lainnya yang mungkin dikembangkan oleh Sekolah Alam Lampung dalam mengoptimalkan pendidikan agama Islam belum terungkap. Untuk itu, perlu kiranya dilakukan penelitian yang akan mengungkap secara komprehensif metode apa saja yang dikembangkan Sekolah Alam Lampung dalam pembelajaran PAI.

\section{METODE PENELITIAN}

Penelitian ini bertujuan untuk menjawab dua hal, yakni metode apa saja yang digunakan sekolah alam dalam pembelajaran PAI di sekolah, serta faktor pendukung dan penghambat dalam pelaksanaan PAI di sekolah. Sekolah Alam Lampung menjadi sasaran penelitian ini karena untuk wilayah Lampung hanya terdapat satu sekolah alam yakni Sekolah Alam Lampung. Penelitian dilakukan pada tahun 2011 dengan menggunakan pendekatan kualitatif dengan analisis deskriptif. Data diperoleh melalui observasi dan wawancara mendalam terhadap pengurus dan guru SAL, peserta didik, orang tua murid, serta masyarakat di sekitar SAL.

Jika dikaitkan dengan Renstra Kementerian Agama tahun 2010-2014, penelitian ini relevan dengan pencapaian program Pendidikan Islam yakni untuk peningkatan Akses Dan Mutu Pendidikan Agama Islam Pada Sekolah. Keluaran (outputs) yang hendak dihasilkan dari kegiatan ini adalah meningkatnya mutu Pendidikan Agama Islam di Sekolah.

\section{Tinjauan Pustaka}

Peraturan Menteri Agama No. 16 Tahun 2010 pasal 1 menyebutkan bahwa pendidikan agama 
adalah pendidikan yang memberikan pengetahuan dan membentuk sikap, kepribadian, dan keterampilan peserta didik dalam mengamalkan ajaran agamanya, yang dilaksanakan sekurangkurangnya melalui mata pelajaran pada semua jalur, jenjang dan jenis pendidikan.

Selanjutnya untuk menilai keberhasilan Pendidikan Agama Islam di sekolah dapat dilihat dari beberapa indikator yang telah ditentukan oleh Direktorat Pendidikan Islam Kementerian Agama, (sumber: http://pendis.kemenag.go.id/kerangka/ pais.htm) yakni: 1) proses belajar mengajar PAI berjalan lancer, 2) sekolah memiliki sarana ibadah yang memadai, 3) warga sekolah yang beragama Islam aktif melaksanakan sholat, puasa pada waktunya, 4) tampilan, prilaku dan sikap siswa dan segenap unsur pendidikan di sekolah pada setiap waktu mencerminkan nuansa islami, 5) ceramah/ diskusi/seminar agama digalakkan dalam berbagai kegiatan luar sekolah, 6) sekolah menggalakkan aktivitas keagamaan, seperti peringatan HBI, pengumpulan infaq, aktivitas belajar al-Quran, dan lain sebagainya, 7) hasil belajar memenuhi standar isi dan kelulusan.

Efektivitas pendidikan agama di sekolah telah ditunjukkan dengan salah satunya adalah temuan dari hasil penelitian Muhaimin dkk (Muhaimin, 2008: 301). Hasil penelitian menunjukkan bahwa kegiatan-kegiatan dan praktik keagamaan yang dilaksanakan secara terprogram dan rutin di sekolah dapat mentransformasikan dan menginternalisasikan nilai-nilai agama secara baik pada diri siswa SMUN di Kodya Malang. Agama menjadi sumber nilai dan pegangan dalam bersikap dan berperilaku baik dalam lingkup pergaulan, belajar, olah raga, dan lain-lain.

Terkait dengan pembelajaran pendidikan agama di sekolah, (Muhaimin, 2008: 111) merangkum berbagai kritik yang digelintirkan oleh berbagai pihak mengenai pendidikan agama di sekolah yang dipandang perlu untuk dicermati, yakni sebagai berikut: 1) pendidikan Agama Islam lebih terkonsentrasi pada persoalan-persoalan teoritis keagamaan yang bersifat kognitif dan amalan ibadah yang bersifat praktis, dan kurang terorientasi pada bagaimana mengubah pengetahuan agama yang kognitif menjadi makna dan nilai yang perlu diinternalisasikan dalam diri siswa, 2) metodologi PAI berjalan secara konvensional-tradisional, dan monoton, 3) kegiatan PAI kebanyakan bersifat menyendiri, kurang berinteraksi dengan yang lain, 4) pendekatan PAI cenderung normatif, tanpa ilustrasi konteks sosial budaya, 5) guru PAI terlalu terpaku pada GBPP mata pelajaran PAI, 6) hubungan antara guru PAI dan siswa lebih berperspektif doktriner sehingga kurang tercipta suasana hubungan kritisdinamis yang dapat berimplikasi pada peningkatan daya kreativitas, etos ilmu, dan etos kerja.

Berbagai kritik terhadap pendidikan agama di sekolah tersebut seharusnya memacu pihakpihak terkait khususnya pengelola sekolah untuk memperbaiki penerapan pendidikan agama di sekolah. Hal tersebut dibutuhkan agar pendidikan agama dapat berhasil diterapkan di sekolah, minimal sesuai dengan indikator yang telah ditetapkan Kementerian Agama.

Salah satu sekolah yang telah mengembangkan kurikulum pembelajaran PAI di sekolah adalah sekolah alam. Kurangnya jam pelajaran agama yang hanya dialokasikan dua jam pelajaran disiasati dengan berbagai hal diantaranya dengan mengintegrasikan pendidikan agama dengan mata pelajaran lainnya.

Sekolah Alam merupakan sekolah yang berbasiskan alam serta memanfaatkan alam sebagai metode pembelajarannya. Sekolah alam bukan hanya mencoba mengajak murid lebih dekat dengan alam, lebih dari itu sekolah ini berusaha memanfaatkan alam sebagai media murah untuk mentransfer ilmu kepada murid secara optimal. Siswa diberikan kebebebasan dalam menuangkan kreatifitas yang mereka sesuai dengan bakat dan kemampuan mereka masing-masing. Itulah mengapa sebagian besar aktivitas belajarnya dilakukan di luar ruang. Siswa diajak langsung belajar di hutan, gunung dan laut. Alam memberi banyak inspirasi dan mengajak berfikir realistis. Anak diajak untuk lebih dekat dengan alam sehingga diharapkan dia dapat tumbuh menjadi seorang yang bijaksana.

Salah satu metode pembelajaran yang diterapkan sekolah alam untuk mengembangkan PAI adalah dengan model webbed (jaringan). Model webbed (jaringan) ini merupakan salah satu dari 10 model pendekatan pembelajaran integratif yang dikemukakan oleh Fogarty. Model ini diartikan sebagai pendekatan tematik, untuk mengintegrasikan mata pelajaran. Pendekatan tematik untuk pengembangan kurikulum diawali dengan sebuah tema (Aripin, 2009: 62).

\section{PEMBAHASAN \\ Sejarah Berdiri Sekolah Alam Lampung}

Berdasarkan wawancara dengan Ir. Hj. Citra Persada, M.Sc. (pendiri dan pemilik yayasan An- 
Naqqara yang menaungi Sekolah Alam Lampung) (2 Maret 2010), berdirinya Sekolah Alam Lampung diawali oleh perhatiannya pada dunia pendidikan. Beliau berasumsi bahwa krisis perilaku yang terjadi akhir-akhir ini pada khususnya generasi muda dapat ditangani dengan pendidikan agama. Berdasarkan asumsi tersebut kemudian beliau mencari sekolah bagi anaknya dengan dua kriteria yakni sekolah yang mendidik siswanya dengan nilai-nilai agama dan sekaligus menerapkan kurikulum internasional. Sekolah dengan kurikulum internasional sengaja dipilih oleh beliau lantaran beban belajar yang tidak memberatkan peserta didik.

Salah satu alternatif sekolah yang dapat merealisasikan keinginan beliau terhadap pentingnya pendidikan agama kala itu adalah pondok pesantren. Namun ternyata beliau tidak menemukan diterapkannya kurikulum internasional di dalam pondok pesantren. Berdasarkan ketidakpuasannya terhadap beberapa lembaga pendidikan yang ada saat itu, maka timbul ide untuk mendirikan sendiri sebuah sekolah. Sekolah dengan kurikulum yang tidak terlalu berat bebannya, lebih fokus, dan agama menjadi perilaku sehari-hari, bukan sekedar dipelajari di dalam kelas.

Ide tersebut kemudian dapat direalisasikan ketika beliau bertemu dengan salah satu dosen UNILA, Ir. Hesti Kusumarini, yang sebelumnya merupakan Direktur Sekolah Alam Bandung. Setelah mengundang Ir. Lendo Novo (Penggagas berdirinya sekolah alam di Indonesia) untuk berdiskusi seputar rencana pendirian sekolah alam, maka pada tahun 2003 dibukalah sekolah alam tersebut dengan bertempat di pekarangan rumah ibu Citra sendiri. Di sekitar pekarangan rumah tersebut terdapat lahan kosong milik pemerintah yang lumayan luas, bahkan juga terdapat hutan monyet. Sekolah tersebut memiliki peserta didik berjumlah 8 orang dengan 4 orang tenaga pendidik. Peserta didik diantaranya adalah anak dari ibu Citra sendiri, serta anak-anak di sekitar rumah beliau.

Seiring dengan bertambahnya jumlah peserta didik, maka kebutuhan untuk menyediakan tempat belajar yang lebih luas pun semakin meningkat. Sehingga pada tahun 2006 SAL berpindah tempat ke lokasi di daerah Way Huwi, Kabupaten Lampung Selatan. Lokasi tersebut merupakan lahan keluarga yang dialokasikan untuk SAL seluas 2 hektar. Sementara ini lahan yang sudah terpakai untuk SAL mencapai 1,5 hektar.

Mengenai legalitas SAL, Dinas Pendidikan Kabupaten Lampung Selatan mengeluarkan izin operasional secara resmi pada tahun 2006 dengan No. 421/1484/111.02/2006 untuk TK dan No. $421 / 1485 / 111.02 / 2006$ untuk SD. Izin tersebut didapat SAL ketika telah berpindah lokasi ke Way Huwi. Sebelumnya, ketika SAL masih berada di pekarangan rumah ibu Citra yang berlokasi di Bandar Lampung, Pemerintah Kotamadya Bandar Lampung tidak mau mengeluarkan izin karena SAL tidak memenuhi kriteria yang diantaranya adalah kelas yang tidak permanen.

Saat ini, SAL sudah memiliki jenjang pendidikan dari TK hingga Sekolah Menengah. Selain itu, juga terdapat PAUD yang dinamakan PAUD Alam. Berbeda dengan TK, PAUD Alam didirikan dengan tujuan untuk mengakomodasi warga lokal yang ingin menyekolahkan anaknya di SAL. Dengan demikian, biaya untuk PAUD Alam dimintakan secara sukarela bahkan hampir gratis.

Dalam Profil Sekolah Alam Lampung tercantum visi, misi, dan tujuan dari SAL. Visi Sekolah Alam Lampung yakni "menjadi sekolah yang dapat mendidik untuk mengembalikan manusia pada tujuan penciptaan, yaitu menjadi pemimpin yang bertaqwa (SQ), berakhlak (EQ), dan berilmu (IQ)". Sementara misinya adalah: a) Membangun sistem pendidikan berbasis alam dengan kualitas pembelajaran berstandar nasional dan internasional. b) Menyelenggarakan pendidikan yang dapat memberi tauladan dalam pengembangan karakter, menggunakan metode "active learning" dan "learning by doing" dan c) Menjadi sekolah unggul dan dapat dinikmati semua kelompok masyarakat di Propinsi Lampung.

Selain visi dan misi tersebut di atas, Sekolah Alam Lampung memiliki tujuan pendidikan sebagai berikut: 1) menghasilkan manusia yang berkualitas, berakhlak baik (akhlaqul karimah), berilmu pengetahuan yang memadai (ulil albab), berjiwa pemimpin (leadership/khalifah), dan memiliki kreativitas (entrepreneurship). 2) Menyediakan lembaga pendidikan alternative yang dapat memperluas kesempatan pendidikan masyarakat di Provinsi Lampung dengan sistem subsidi silang. Dan 3) Membentu percepatan peningkatan SDM berkualitas di Provinsi Lampung melalui suatu bentuk sistem pendidikan yang terpadu sehingga mampu bersaing dalam menghadapi era globalisasi.

\section{Kondisi Riil Sekolah Alam Lampung Tenaga Pendidik dan Kependidikan}

Berawal dari hanya 4 orang tenaga pendidik dan kependidikan, kini telah terdapat 31 orang 
tenaga pendidik dan kependidikan di SAL. 5 orang diantaranya merupakan tenaga kependidikan, sementara lainnya adalah tenaga pendidik. Dari keseluruhan tenaga pendidik, baru terdapat satu orang dengan kualifikasi akademik Strata 2 (S2) dan yang lainnya berpendidikan strata 1 (S1).

Ditinjau dari PP No.19 tahun 2005 tentang Standar Nasional Pendidikan pada pasal 29, tenaga pendidik yang dimiliki SAL sudah sesuai dengan kualifikasi pendidikan minimum yakni S1. Namun terkait ayat lainnya di pasal tersebut, tenaga pendidik SAL tidak memenuhi kriteria sebagai tenaga pendidik yang memiliki latar belakang pendidikan pada program pendidikan serta memiliki sertifikat profesi guru. Hanya terdapat satu orang tenaga pendidik yang memenuhi kriteria tersebut.

Tenaga pendidik merupakan komponen terpenting bagi SAL. Untuk itu, proses rekrutmen tenaga pendidik dilakukan secara ketat. Tenaga pendidik harus memahami agama dengan baik, bahkan harus bisa membaca Alquran. Selain itu, tenaga pendidik juga harus mengikuti pengajian setiap minggunya di organisasi manapun. Hal itu dimaksudkan agar wawasan keagamaan tenaga pendidik selalu bertambah (Kepala SD, 22 Februari 2011).

Selengkapnya, dalam profil SAL disebutkan beberapa kriteria yang harus dipenuhi oleh calon tenaga pendidik: berpendidikan minimal S1, dengan IPK minimal 2,7 dari Perguruan Tinggi Negeri ternama, memiliki kemampuan berkomunikasi yang baik (Inggris/TOEFL minimum 450), memiliki basic dan pemahaman agama (Islam) yang baik, dapat tercermin dalam perilaku atau akhlak seharihari, serta ibadah dan hafalan surat, memiliki jiwa kreativitas dan explorasi (penelitian) yang tinggi, dan memiliki visi ke depan terhadap dunia pendidikan di Indonesia.

Untuk memenuhi kriteria tersebut, calon tenaga pendidik akan dinilai oleh tim seleksi guru dengan melewati tahap wawancara dan microteaching.

\section{Peserta Didik}

Dengan memperhatikan data perkembangan siswa yang tercantum dalam dokumen Sekolah Alam lampung, dapat diketahui bahwa perkembangan peserta didik selalu mengalami peningkatan dari tahun ke tahun. Untuk peserta didik tingkat SD saja, sejak tiga tahun terakhir yakni tahun pelajaran 2008/2009 hingga 2010/2011 mencapai angka
$84,107,128$. Hal ini menunjukkan bahwa SAL semakin dikenal dan dipercaya oleh masyarakat luas sebagai alternatif lembaga pendidikan di kabupaten Lampung Selatan pada khususnya.

Mengenai seleksi masuk, berdasarkan wawancara dengan Direktur SAL, Ibu Hesti (1 Maret 2011) menyatakan bahwa SAL meniadakan seleksi akademis bagi calon peserta didik. Hal itu berarti bahwa SAL tidak mengutamakan kemampuan akademis calon peserta didik namun lebih menghargai potensi beragam yang dimiliki setiap anak. Seleksi masuk calon peserta didik lebih kepada mempertimbangkan 3 hal, yakni usia, emosi, dan orang tua. Usia yang dimaksud adalah apakah si-anak sudah memasuki usia sekolah sesuai dengan jenjang yang akan dimasuki. Jika usianya belum mencukupi, maka akan direkomendasikan untuk masuk ke jenjang sebelumnya.

Kemudian tahap seleksi selanjutnya adalah dengan sit-in. calon peserta didik diujicobakan untuk masuk dan mengikuti kegiatan belajar mengajar di sebuah kelas selama tiga hari. Dari situ akan terlihat apakah si anak termasuk dalam kategori anak berkebutuhan khusus (special need) atau tidak. Jika memang ia termasuk dalam special need, selama ia tidak memiliki gangguan emosi dan perilaku yang parah maka akan diterima. Namun jika sebaliknya, maka SAL akan menolak calon peserta didik tersebut lantaran tidak memiliki SDM yang memadai.

Kemudian seleksi terakhir adalah wawancara kepada orang tua calon peserta didik. Inti dari wawancara tersebut adalah untuk mengetahui kesediaan orang tua dalam bekerja sama dengan menerima konsep SAL yang tidak berorientasi nilai, tidak mengutamakan akademis, namun mengutamakan proses.

Terdapat banyak peserta didik yang masuk ke SAL yang merupakan pindahan dari sekolah lain. Banyak pula diantara mereka yang pindah ke SAL lantaran dikeluarkan oleh sekolah sebelumnya karena kenakalannya. Hal itu tidak menjadi kendala bagi SAL karena memang mentreatment anak yang nakal merupakan panggilan tugas bagi tenaga pendidik di SAL (Hesti, 1/3/2011).

Banyaknya peserta didik yang merupakan pindahan dari sekolah lain mengindikasikan bahwa animo masyarakat untuk memasukkan anaknya ke SAL semakin meningkat. Selain itu, keberadaan SAL mendapat kepercayaan masyarakat sebagai lembaga pendidikan yang dapat mengubah perilaku anak. 


\section{Sarana Prasarana}

Sebagai pendukung kegiatan belajar mengajar, tentunya dibutuhkan sarana prasarana yang memadai. SAL dengan memanfaatkan sumber daya alam, menyediakan sarana prasarana yang dapat menyatu dengan alam. Terbukti dengan dibangunnya ruang belajar peserta didik yang berbentuk saung. Dengan desain rumah adat Lampung, saung tersebut dibangun dengan menggunakan bahan yang ramah lingkungan berupa kayu yang memang banyak tersedia di wilayah sekitar SAL (Hesti, wawancara 1/3/2011).

Selengkapnya, dalam profil SAL disebutkan secara rinci sarana prasarana yang dimiliki SAL adalah sebagai berikut: saung sebagai ruang belajar indoor, perpustakaan, kantor, children playground, area outbond, green house (rumah pembibitan), lahan pertanian hortikultura, kandang ternak, kolam ikan, ruang audiovisual: TV, VCD, Tape, lapangan bermain/upacara/olahraga.

Meskipun SAL merupakan sebuah sekolah dengan konsep alam, namun bukan berarti SAL tidak mengikuti perkembangan zaman. Untuk memenuhi tuntutan globalisasi, SAL juga menyediakan laboratorium teknologi-informasi dan komunikasi (ICT).

\section{Struktur Organisasi dan Pembiayaan}

SAL memiliki manajemen pengelolaan yang terdiri dari (sumber: profil SAL): Yayasan Sekolah Alam Lampung (Yayasan An-Naqqara), yang berperan sebagai pengelola SAL secara umum, berkenaan dengan penyediaan sarana prasaran fisik sekolah, pembuatan kurikulum, penelitian dan pengembangan SAL.

Syuro guru SAL, berperan sebagai pengelola keuangan dan kegiatan SAL secara spesifik dan pelaksanaan kegaitan belajar mengajar. Investor, berperan sebagai penyandang dana untuk pembangunan dan pengembangan SAL yang berdasarkan kesepakatan akan mendapatkan bagi hasil atau profit dari SAL.

Sementara struktur organisasi sekolah terdiri dari: Kepala sekolah (ketua syuro guru), direktur sekolah (koordinator kurikulum dan pengembangan sekolah), staf administrasi, staf guru (guru kelas, paruh waktu, guru ekstrakurikuler), pembantu umum, dan penjaga sekolah. Pergantian struktur organisasi, terutama Kepala Sekolah, sampai saat ini seperti diakui oleh Direktur SAL (wawancara, 1/3/2011) belum ada aturan mengenai hal itu dalam AD/ART Yayasan SAL. Meskipun demikian, setiap tahunnya terdapat rapat kerja yang didalamnya akan dibahas dan dievaluasi kinerja seluruh komponen SAL.

Mengenai sumber dana dan pembiayaan, beliau melanjutkan bahwa hingga kini SAL menerapkan sistem subsidi silang. Terdapat 20\% peserta didik yang tidak dibebankan biaya berupa uang bangunan dan uang sekolah yaitu bagi anak yatim dan anak guru. Sebanyak 30\% peserta didik membayar 50\% dari keseluruhan biaya, yakni bagi orang tua yang kurang mampu. Selain itu, peserta didik diwajibkan membayar seluruh biaya sekolah.

Selain berasal dari biaya peserta didik, SAL juga menerima donator tidak tetap baik dari Pemerintah maupun perorangan. Diantaranya adalah Dinas Pendidikan Provinsi dengan membangunkan sebuah kelas, Dinas Pendidikan Kabupaten membangunkan kelas PAUD, Laboratorium science yang dibangun oleh Pemerintah Provinsi, dan beberapa komputer dari Kemkominfo. Selain itu, SAL juga mendapatkan dana BOS sejak tahun 2007. Pihak lain yang menjadi donator tidak tetap diantaranya adalah para pengusaha. SAL juga sering mendpatkan bantuan sponsor melalui acara-acara yang diadakan SAL.

\section{Kurikulum}

Kurikulum SAL mengacu pada standar kompetensi Kementerian Pendidikan Nasional yang diperkaya dengan kurikulum khas sekolah alam (green education). Sistem kurikulum tersebut terintegrasi melalui metode spiderweb. Kurikulum SAL terintegrasi dalam metode belajar sebagai berikut: Akhlak melalui konsep tauladan untuk pengembangan SQ (Spiritual Quotient), EQ (Emotional Quotient), scientific (ilmu pengetahuan) melalui mencatat, melakukan eksperimen sampai membentuk sebuah teori, leadership, kegiatan utama untuk kepemimpinan ini adalah outbond mental education, dan enterpreuneurship (kewirausahaan) dikembangkan melalui praktek kegiatan bisnis mingguan di lingkungan sekolah dan pada bulan tertentu mengadakan market day (sumber: Profil SAL)

Untuk mendukung enterpreunership yang berbasis project, SAL menyediakan tiga macam laboratorium yang dipilih berdasarkan potensi lokal daerah Lampung. Ketiga laboratorium tersebut adalah laboratorium budaya, bioteknologi, dan teknologi-informasi-komunikasi (ICT). Laboratorium budaya dikembangkan berdasarkan pertimbangan bahwa Lampung memiliki potensi 
yang besar dalam budaya, alam, dan pariwisata. Sementara untuk laboratorium bioteknologi dipilih lantaran Lampung kaya akan sector pertanian, dan laboratorium ICT dikembangkan karena merupakan tuntutan zaman (Citra, wawancara 2/3/2011).

\section{Evaluasi}

SAL menerapkan tiga jenis evaluasi bagi peserta didik. Pertama, berupa portofolio yang dibagikan kepada peserta didik pada bulan ke dua setiap semester. Kedua adalah raport narasi yang dibagikan setiap bulan keempat pada setiap semester. Terakhir, adalah raport penilaian akademis yang sesuai dengan ketentuan Dinas Pendidikan.

Portofolio dapat diartikan sebagai kumpulan karya siswa yang disusun secara sistematis dan terorganisir sebagai hasil dari usaha pembelajaran yang telah dilakukannya dalam kurun waktu tertentu. Dengan demikian, penilaian portofolio dilakukan untuk menilai setiap aspek perkembangan siswa termasuk perkembangan minat, sikap, dan motivasi (Sanjaya, 2008: 363, 368). Untuk itu maka kiranya sangat tepat jika SAL menerapkan adanya penilaian portofolio karena dapat memantau perkembangan peserta didik secara komprehensif, yang pada gilirannya dapat menjadi acuan bagi tercapainya tujuan pembelajaran.

Selain itu, langkah SAL melakukan penilaian portofolio jika dilihat dari segi manfaat portofolio menjadi sangat signifikan bagi proses belajar mengajar. Diantara beberapa manfaat potofolio yakni: dapat memberikan gambaran yang utuh dan autentik tentang perkembangan kemampuan siswa (pengetahuan, sikap dan keterampilan), dapat menumbuhkan motivasi belajar dengan diberikannya reinforcement, dapat mendorong orang tua siswa untuk aktif terlibat dalam proses pembelajaran siswa (Sanjaya, 2008: 364).

Evaluasi yang berupa raport narasi merupakan laporan perkembangan peserta didik yang bertujuan untuk melihat akhlak peserta didik sesuai dengan item-item yang telah ditentukan SAL. Laporan narasi ini tidak mencantumkan angka melainkan kategori pencapaian peseta didik yang terbagi dalam 3 kategori: perlu bimbingan, berkembang, dan mandiri. Terdapat pula raport yang berupa penilaian hasil belajar siswa yang berbentuk angka, sesuai dengan format yang telah ditetapkan Dinas Pendidikan.

Selain ketiga jenis laporan perkembangan peserta didik di atas, SAL juga mengikutsertakan seluruh peserta didiknya dalam Ujian Nasional.
Hal itu dikarenakan kebutuhan masyarakat sekitar yang masih cenderung mengutamakan penilaian akademis. Kedepannya, SAL berencana untuk membebaskan peserta didik untuk mengikuti maupun tidak mengikuti Ujian Nasional.

\section{Prestasi}

Hingga penelitian ini dilakukan, SAL baru meluluskan peserta didik untuk tingkat SD sebanyak dua kali yakni pada tahun pelajaran 2008/2009 dan 2009/2010. Seluruh peserta yang mengikuti Ujian Akhir Berstandar Nasional dapat lulus dengan baik. Bahkan terdapat satu peserta ujian yang berhasil mencapai nilai 9.50 untuk mata ujian Matematika. Hal ini mengindikaskan bahwa meskipun nilai akademis bukan menjadi hal yang utama di SAL, namun peserta didik SAL dapat lulus dengan nilai akademis yang maksimal.

Untuk prestasi non akademis, SAL sering menjuarai perlombaan yang diadakan baik di tingkat kabupaten maupun provinsi. Diantaranya adalah lomba mewarnai, mendongeng, renang, karate, dan lainnya. Bahkan, SAL terpilih menjadi nominator sekolah adiwiyata Provinsi Lampung.

\section{Pendidikan Agama Islam di Sekolah Alam Lampung}

Untuk menghasilkan peserta didik yang berkualitas dengan memiliki SQ, EQ, dan IQ yang berkembang maksimal dan seimbang, maka SAL menempuh berbagai upaya untuk mewujudkan hal tersebut. Diantaranya adalah dengan mengedepankan pendidikan agama yang tidak hanya mencapai ranah kognitif, namun hingga internalisasi nilai-nilai agama dalam kehidupan peserta didik. Beberapa terobosan yang dilakukan SAL untuk mengefektifkan pendidikan agama Islam bagi peserta didik dapat tergambar dalam penjelasan berikut:

\section{Keteladanan}

Abdullah Nasih 'Ulwan (2007, dalam Aripin, 2009: 80) mengatakan bahwa keteladanan merupakan metode yang berpengaruh dan terbukti paling berhasil dalam mempersiapkan dan membentuk aspek moral, spiritual, dan etos sosial anak. Mengingat pendidik adalah figur terbaik dalam pandangan anak, yang tindak tanduk dan sopan santunnya disadari atau tidak, akan ditiru oleh mereka.

Keteladanan merupakan faktor utama yang dituntut dari seluruh tenaga pendidik di SAL. 
Tidak hanya guru agama saja yang harus menjadi teladan bagi peserta didik namun semua guru harus menjaga lisan dan sikap agar menjadi contoh bagi anak-anak (Kepala SD, 23/2/2011). Dengan demikian maka kemudian semua guru harus berperan sebagai guru agama (Citra, wawancara 2/3/2011). Daulay (2007: 40) mengatakan ada kesan di berbagai sekolah umum baik negeri maupun swasta bahwa pendidikan agama menjadi tanggung jawab guru-guru agama saja, sedangkan guru-guru mata pelajaran lain merasa kurang ada hubungannya dengan pendidikan agama. Hal tersebut terbukti tidak berlaku di Sekolah Alam Lampung. Ketika terdapat seorang tenaga pendidik yang bertingkah laku tidak sesuai dengan akhlak karimah, maka tenaga pendidik lain akan mengingatkannya.

\section{Integrasi PAI ke dalam semua mata pelajaran}

Dengan menggunakan metode spiderweb, peserta didik akan lebih menguasai materi-materi yang berhubungan dengan agama. Karena dalam setiap mata pelajaran, tenaga pendidik akan selalu mengaitkan tema yang sedang disampaikan dengan nilai-nilai agama. Misalkan ketika menyampaikan materi yang bertema air, tenaga pendidik akan mengaitkan air dengan Sang pencipta, atau dengan bagaimana memanfatkan air agar tidak mubazir, mengaitkannya dengan keajaiban air, atau kisah nabi yang berkaitan dengan air, dan sebagainya. Atau ketika menyampaikan materi project kepada peserta didik, maka tenaga pendidik akan menyampaikan bahwa Nabi Muhammad saw juga telah berdagang sejak beliau baligh.

Hal tersebut di atas sejalan dengan apa yang dikatakan Soedjatmoko dan Mochtar Buchori (dalam Muhaimin, 2008: 101) bahwa perlu adanya interaksi dan sinkronisasi antara pendidikan agama dengan pendidikan non agama, begitu pula antara guru PAI dengan guru mata pelajaran lain dalam pendidikan agama di sekolah. Dengan mensinkronkan pendidikan agama dengan mata pelajaran lain, peserta didik akan dapat lebih memahami bahwa agama terkait dengan segala aspek dalam kehidupan.

\section{Melibatkan seluruh komponen sekolah dan Orang Tua}

Daulay (2007: 44) mengatakan bahwa untuk mendukung kesuksesan pendidikan agama harus ada jaringan kerja antara rumah tangga, sekolah, dan masyarakat, setidaknya bagaimana hubungan sekolah dengan rumah tangga. Sekolah Alam
Lampung menuntut seluruh komponen sekolah untuk menyukseskan penanaman nilai-nilai agama di sekolah. Hal itu dengan melibatkan seluruh tenaga pendidik dan kependidikan secara aktif dalam memperhatikan dan mengawasi tingkah laku peserta didik di sekolah setiap saat. Ketika seorang anak menampakkan tingkah laku yang kurang baik, seperti membuag sampah tidak pada tempatnya, maka siapapun yang melihat akan menegurnya tanpa harus menunggu guru agama terlebih dahulu.

Orang tua siswa juga dituntut untuk terlibat aktif dalam memantau perkembangan akhlak anak. Diterapkannya buku komunikasi antara guru dan orangtua salah satunya bertujuan untuk memantau perkembangan anak.

\section{Metode pembelajaran yang mengutamakan praktik dan pengalaman}

Temuan dari hasil penelitian Muhaimin dkk (Muhaimin, 2008: 301) menyatakan bahwa kegiatankegiatan dan praktik keagamaan yang dilaksanakan secara terprogram dan rutin di sekolah dapat mentransformasikan dan menginternalisasikan nilai-nilai agama secara baik pada diri siswa SMUN di Kodya Malang. Sehingga agama menjadi sumber nilai dan pegangan dalam bersikap dan berperilaku baik dalam lingkup pergaulan, belajar, olah raga, dan lain-lain.

Sekolah Alam Lampung setiap harinya menerapkan praktek baik dalam bentuk praktek ibadah maupun penerapan akhlak mulia. Seperti halnya TK, tidak tersedianya jam khusus untuk materi agama menjadikan praktek sebagai satusatunya metode untuk menyampaikan nilai-nilai agama. Menjaga kebersihan, menjaga lingkungan, dan sebagainya akan langsung dipraktekkan oleh tenaga pendidik agar peserta didik dapat melihat kemudian mencontohnya.

Begitu pula dengan praktek ibadah lainnya, seperti misalnya sholat dhuha yang dilaksanakan setiap hari oleh seluruh peserta didik dari tingkat PAUD hingga sekolah menengah. Sholat dhuha dilaksanakan secara berjamaah dengan imamnya adalah peserta didik sendiri jika dinilai sudah mampu untuk menjadi imam. Sementara untuk waktu pelaksanaan bermacam-macam, disesuaikan dengan kondisi kelas masing-masing.

\section{Memanfaatkan alam sebagai media pembelajaran}

Dari hasil pengamatan peneliti ditemukan bahwa hampir disetiap batang pohon maupun dinding-dinding ruang dipenuhi dengan tulisan- 
tulisan. Tulisan tersebut berisi hadis ataupun kata-kata bijak yang mencerminkan akhlak Islam. Berdasarkan wawancara dengan Kepala Sekolah Menengah (22 Februari 2011) dikatakan bahwa tulisan yang banyak diletakkan diberbagai tempat sebenarnya memanfaatkan keberadaan alam, sebagai upaya untuk membangun kebiasaan akhlak anak sejak dini melalui tulisan.

Memanfaatkan alam sebagai media untuk membangun akhlak peserta didik sedikit banyak membawa pengaruh bagi peserta didik. Hal ini didukung oleh pengakuan dari salah seorang peserta didik yang diwawancarai peneliti pada tanggal 22/2/2011. Peserta didik tersebut mengatakan bahwa tulisan-tulisan yang menempel di dinding atau di pohon itu banyak yang kemudian bisa dihapal dan diikuti, misalnya jangan makan berdiri, dan lainnya.

\section{Integrasi PAI dalam intra/ekstra-kurikuler}

Ungkapan pendiri dan pemilik Sekolah Alam Lampung bahwa peserta didik tidak terlepas dari perilaku ajaran agama sejak masuk hingga pulang sekolah memang benar adanya. Sebelum dimulainya pembelajaran saja, SAL menerapkan satu bentuk kegiatan yang disebut morning activity setiap harinya. Kegiatan tersebut dilaksanakan selama 30 menit sebelum dimulai pembelajaran. Didalamnya diisi dengan hapalan surat pendek ataupun doa-doa.

Kemudian di dalam semua pelajaran, setiap tenaga pendidik harus mencontohkan akhlak yang baik bagi anak. Hal itu menjadikan agama bukan hanya dalam materi, tetapi dalam semua aktivitas harus senantiasa menjaga akhlak (Kepala SD, 23/2/2011).

SAL juga memperingati semua hari besar Islam dengan kegiatan yang bermacam-macam. Jenis kegiatan tersebut ditentukan melalui rapat guru yang diselenggarakan sebulan sebelum kegiatan dilaksanakan. Misalnya dengan lomba mewarnai, menghapal Alquran, lomba azan, dan sebagainya. Kegiatan tersebut melibatkan semua murid, mulai dari PAUD hingga SM. Tujuan dari peringatan hari besar Islam adalah agar siswa tahu mengenai sejarah Islam.

Tidak hanya hari besar Islam, hari besar dunia juga diperingati melalui berbagai kegiatan. Misalnya pada hari pohon, murid diberikan pengarahan tentang bagaimana manfaat pohon bagi kehidupan, kemudian diajarkan juga bahwa dalam agama diperintahkan untuk menjaga dan memelihara pohon (Kepala SD, 23/2/ 2011).
Jika ditinjau dari indikator keberhasilan Pendidikan Agama Islam diSekolah yangdirumuskan oleh Pendis Kemenag, maka pembelajaran PAI di SAL sudah termasuk dalam kategori berhasil. Hal itu terlihat dari tercapainya seluruh indikator keberhasilan, yakni proses belajar mengajar PAI berjalan lancar, sekolah memiliki sarana ibadah yang memadai, warga sekolah yang beragama Islam aktif melaksanakan sholat, puasa pada waktunya, tampilan, prilaku dan sikap siswa dan segenap unsur pendidikan di sekolah pada setiap waktu mencerminkan nuansa islami, ceramah/diskusi/ seminar agama digalakkan dalam berbagai kegiatan luar sekolah, sekolah menggalakkan aktivitas keagamaan, seperti peringatan HBI, pengumpulan infaq, aktivitas belajar Alquran, dan lain sebagainya, dan yang terakhir adalah hasil belajar memenuhi standar isi dan kelulusan.

\section{Hambatan}

Hambatan yang dirasakan SAL secara keseluruhan berkaitan dengan sumber daya manusia, sulitnya mencari calon tenaga pendidik yang memiliki Indeks Prestasi tinggi dan bersedia dengan ikhlas mengajar di SAL. Artinya bahwa calon tenaga pendidik tersebut dapat menerima dengan ikhlas imbalan yang diberikan SAL yang relatif lebih rendah daripada sekolah lain.

Hambatan lain terkait dengan masyarakat lokal yang belum dapat menerima paradigma SAL sebagai sekolah yang memanfaatkan alam sebagai media pembelajaran, juga tidak diutamakannya kemampuan kognitif siswa semata sebagai target pencapaian pembelajaran. Karena itulah maka sebagian besar peserta didik SAL berasal dari daerah yang justru jauh jaraknya dari SAL.

Perbedaan kemampuan peserta didik dalam memahami agama juga menjadi kendala bagi guru ketika menyampaikan materi agama. Perbedaan tersebut disebabkan oleh tidak adanya seleksi mengenai pemahaman keagamaan calon peserta didik.

\section{Dukungan}

Faktor pendukung pencapaian keberhasilan PAI berasal dari SAL sendiri dan juga orang tua murid. Secara rinci faktor pendukung tersebut adalah sebagai berikut: guru dapat bebas berekspresi, sistem pembelajaran tidak monoton, tidak harus di dalam kelas saja, materi tidak dibatasi oleh apa yang terdapat dalam kurikulum, guru-guru dapat menyampaikan ide-idenya secara terbuka, 
lingkungan fisik yang alami dapat mendukung pembelajaran, membuat anak dapat bebas bermain dan mengeksplorasi alam, dan pandangan positif orang tua murid terhadap guru.

\section{PENUTUP}

Pembelajaran PAI di Sekolah Alam Lampung menggunakan metode keteladanan, dengan mengharuskan semua guru meskipun bukan guru agama untuk menjadi teladan bagi peserta didik. Kemudian juga melalui integrasi PAI ke dalam semua mata pelajaran dengan menggunakan metode pembelajaran spiderweb. Tenaga pendidik akan mengaitkan tema yang sedang disampaikan dalam setiap mata pelajaran dengan nilai-nilai agama.

Metode lainnya adalah dengan melibatkan seluruh komponen sekolah dan orang tua, yakni melibatkan seluruh tenaga pendidik dan kependidikan untuk secara aktif memperhatikan dan mengawasi tingkah laku peserta didik setiap saat di sekolah. Orang tua siswa juga dituntut untuk terlibat aktif dalam memantau perkembangan akhlak anak melalui buku komunikasi.

Selain itu, SAL setiap harinya menerapkan praktek dalam bentuk praktek ibadah maupun penerapan akhlak mulia. Juga dengan memanfaatkan alam sebagai media pembelajaran yakni dengan menempelkan tulisan-tulisan yang berisi hadis dan kata-kata bijak di batang-batang pohon dan dinding-dinding ruangan. Metode terakhir adalah dengan mengintegrasikan PAI dalam intra/ekstrakurikuler.

Faktor penghambat pembelajaran PAI berkaitan dengan keterbatasan SDM tenaga pendidik, perbedaan kemampuan pemahaman agama peserta didik, serta masyarakat yang belum dapat sepenuhnya menerima keberadaan sekolah alam. Sedangkan faktor pendukung berupa kebebasan guru untuk mengeksplorasi metode dan strategi pembelajaran, lingkungan yang kondusif, dan pandangan positif orang tua terhadap tenaga pendidik.

\section{UCAPAN TERIMA KASIH}

Penelitian ini dibiayai oleh DIPA Balai Litbang Agama Jakarta tahun 2011. Penulis mengucapkan terima kasih kepada semua pihak yang telah berperan dalam penelitian ini. Kepada Kepala Balai Litbang Agama Jakarta, rekan-rekan peneliti, Direktur Sekolah Alam Lampung, dan seluruh informan yang bersedia membantu peneliti menyelesaikan penelitian ini.

\section{DAFTAR PUSTAKA}

Aripin, Syamsul. 2009. Tesis: Pembelajaran Pendidikan Agama Islam Integratif di SMA Islam Al-Izhar Pondok Labu. Jakarta: Sekolah Pascasarjana UIN Syarif Hidayatullah.

Daulay, Haidar Putra. 2007. Pendidikan Islam dalam Sistem Pendidikan Nasional di Indonesia. Jakarta: Kencana. cet. Ke-1.

Herawati, Evi. 2009. Tesis: Pengembangan Kurikulum Pendidikan Agama Islam di Sekolah Alam (Studi Kasus di School of Universe). Jakarta. Konsentrasi Pendidikan Islam Sekolah Pascasarjana UIN Syarif Hidayatullah.

Muhaimin. 2006. Nuansa Baru pendiidkan Islam mengurai benang kusut dunia pendidikan. Jakarta: PT. Rajagrafindo Persada. cet. Ke-1.

Muhaimin. Et. al. 2008. Paradigma Pendidikan Islam: Upaya Mengefektifkan Pendidikan Agama Islam di Sekolah. Bandung: PT. Remaja Rosdakarya. Cet. Ke-4.

Peraturan Menteri Agama RI No.16 Tahun 2010 tentang Pengelolaan Pendidikan Agama pada Sekolah.

Renstra Kementerian Agama tahun 2010-2014

Sanjaya, Wina. 2008. Kurikulum dan Pembelajaran. Jakarta: Kencana Prenada Media Group.

Wahyudi, Imam. 2009. Tesis: Implementasi Pembelajran Terrpadu Model Webbed (Jaring Laba-laba) dalam Meningkatkan Akhlak SIswa (Studi pada Sekolah Alam Lampung Way Huwi Lampung Selatan). Lampung: Program Studi Ilmu Tarbiyah, Konsentrasi Manajemen Pendidikan Islam, Program Pascasarjana IAIN Raden Intan.

\section{Internet:}

http://pendis.kemenag.go.id/kerangka/pais.htm diakses tanggal 04 April 2011

http://pasitb.tripod.com/sanlat1.htm diakses tanggal 04 April 2011 